\title{
KH Domain-Containing, RNA-Binding, Signal Transduction-Associated Protein 3
}

National Cancer Institute

\section{Source}

National Cancer Institute. KH Domain-Containing, RNA-Binding, Signal Transduction-

Associated Protein 3. NCI Thesaurus. Code C162402.

KH domain-containing, RNA-binding, signal transduction-associated protein 3 (346 aa, $\sim 39 \mathrm{kDa}$ ) is encoded by the human KHDRBS3 gene. This protein is involved in the alternative splicing of RNA. 